\title{
INTENSI MAHASISWA YOGYAKARTA BERWIRAUSAHA BERBASIS TEKNOLOGI INFORMASI (TI) ${ }^{1}$
}

\author{
Heru Kurnianto Tjahjono \\ Universitas Muhammadiyah Yogyakarta \\ e-mail: heruutilitas@yahoo.com \\ Tri Maryati \\ Universitas Muhammadiyah Yogyakarta \\ Fauziyah \\ Universitas Muhammadiyah Yogyakarta
}

\begin{abstract}
The purpose of this study is to investigate intention to be entrepreneur among university students in Yogyakarta. Based on modification of TPB (theory of planned behavior) and TAM (technology acceptance model), this research specifically examined whether entrepreneur's personality is an important antecedent to explain attitude, risk perception and subjective norm of entrepreneur based on information technology (IT). This research tested whether attitude, risk perception and subjective norm of entrepreneur based on IT are important predictors to explain students' intention to become entrepreneur based on IT. This research is a replication model proposed by Tjahjono and Palupi (2014). The samples in this research were 300 students from four large universities in Yogyakarta with purposive technique and were analyzed using structural equation modeling (SEM). The results of this research showed that attitude, risk perception, and subjective norm are consequences of entrepreneur's personality and at the same time as antecedents to explain students' intentions to be entrepreneur based on IT.
\end{abstract}

Keywords: TPB, TAM and students intention to be entrepreneur.

\begin{abstract}
Abstrak
Penelitian ini bertujuan untuk menginvestigasi intensi mahasiswa di Yogyakarta berwirausaha. Berbasis pada modifikasi TPB (theory of planned behavior) dan TAM (technology acceptance model), penelitian ini secara spesifik menguji apakah kepribadian berwirausaha merupakan anteseden penting dalam menjelaskan sikap, persepsi resiko dan norma subjektif berwirausaha yang berbasis TI. Selanjutnya apakah sikap, persepsi resiko dan norma subjektif berwirausaha berbasis TI adalah prediktor penting dalam menjelaskan intensi mahasiswa berwirausaha yang berbasis TI. Penelitian ini merupakan replikasi model yang diajukan Tjahjono dan Palupi (2014). Sampel dalam penelitian ini adalah 300 mahasiswa 4 perguruan tinggi besar di Yogyakarta dengan teknik penyampelan secara purposive. Penelitian ini dianalisis dengan menggunakan SEM. Hasil penelitian menunjukkan bahwa sikap, persepsi resiko dan norma subjektif berwirausaha berbasis TI adalah konsekuensi kepribadian berwirausaha sekaligus anteseden intensi berwirausaha berbasis TI.
\end{abstract}

Kata kunci: TPB, TAM dan intensi mahasiswa berwirausaha.

\section{PENDAHULUAN}

Kondisi ekonomi dan bisnis di Indonesia menghadapi sejumlah tantangan meliputi kemiskinan dan pengangguran. Permasalahan kemiskinan

\footnotetext{
${ }^{1}$ Penelitian ini merupakan penelitian Hibah Bersaing yang dibiayai Ditjen Dikti 2013.
}

dan pengangguran seakan seperti penyakit khronis yang tidak berkesudahan. Sejumlah biaya pokok seperti pangan, tempat tinggal, pendidikan dan kesehatan menjadi semain tidak terjangkau oleh sebagian masyarakat Indonesia. Permasalahan di atas sebenarnya dapat di atasi melalui partisipasi masyarakat dalam 
menjalankan aktifitas ekonomi dan bisnis atau sering disebut kewirausahaan (entrepreneurship). Dengan melakukan aktifitas wirausaha memunculkan kekuatan ekonomi dan bisnis yang mandiri sekaligus berpotensi memberikan peluang kerja pada sejumlah orang dan meningkatkan pendapatan masyarakat. Kewirausahaan merupakan proses penerapan kreatifitas dan inovasi dalam memanfaatkan peluang untuk mencapai kehidupan bisnis yang lebih kreatif dan berhasil. Memasyaratkan wirausaha berarti membuka lapangan kerja dan mengurangi angka kemiskinan. Oleh karena itu pengembangan kewirausahaan menjadi isu penting dalam upaya membangun fondasi ekonomi yang lebih kuat.

Catatan di tahun 2012, dalam satu tahun rasio kewirausahaan di Indonesia meningkat dari $0,24 \%$ menjadi $1,56 \%$ (Hasan, 2012). Meski rasio masih relatif kecil di antara sejumlah Negara berkembang di Asia tenggara, namun kenaikan tersebut merupakan fenomena menarik dari sisi akselerasi dalam satu tahun. Rasio ini memberikan harapan sangat baik dalam pembangunan sosial ekonomi bangsa, karena tingkat ketergantungan terhadap pemerintah dalam penyediaan lapangan kerja semakin berkurang.

Berkaitan dengan data wirausaha yang dipaparkan di atas, lulusan SD dan SMP yang berwirausaha mencapai 18-20\%. Sedangkan lulusan sekolah menengah atas sebesar 15,13\% dan ironisnya lulusan perguruan tinggi yang berminat berwirausaha hanya $6,14 \%$. Dengan demikian semakin tinggi pendidikan mereka maka minat berwirausaha justru semakin rendah.

Dewasa ini perkembangan teknologi informasi sedemikian pesat sehingga dalam berbisnis penggunaan teknologi informasi menjadi alat bantu yang bersifat massif di kalangan pelaku bisnis muda. Para mahasiswa di perguruan tinggi adalah sekelompok masyarakat berusia muda yang memiliki kesempatan belajar dan menggunakan teknologi informasi secara lebih baik dibandingkan mereka yang tidak belajar di perguruan tinggi. Oleh karena itu terkait dengan perilaku berwirausaha maka mahasiswa seharusnya memiliki bekal ilmu berwirausaha dan memiliki kapasitas mempelajari teknologi informasi jauh lebih baik daripada lulusan di level SMA dan SMP.
Penelitian sebelumnya mengenai kewirausahaan mahasiswa di salah satu perguruan tinggi swasta Yogyakarta dilakukan Tjahjono dan Ardi (2008) dengan menggunakan teori perilaku rencanaan (theory of planned behavior). Penelitian ini fokus pada intensi berwirausaha dengan menggunakan teknologi informasi sebagai alat bantu sehingga model yang digunakan dalam penelitian ini terkait dengan penggunaan teknologi.

\section{KAJIAN PUSTAKA}

Konsep penelitian yang dikembangkan dalam model penelitian ini berpijak pada teori-teori keperilakuan. Berawal dari teori tindakan beralasan (Theory of Reasoned Action) yang dikembangkan Fishbein and Ajzen (1975) selanjutnya disebut TRA. TRA merupakan teori fundamental dalam menjelaskan studi perilaku. Bagozzi (1992) dalam Dharmmesta (1998) menjelaskan pula bahwa TRA adalah teori yang parsimoni dalam menjelaskan perilaku.

Hasil empiris menunjukkan bahwa TRA telah menjelaskan bahwa sikap terhadap perilaku memang merupakan prediktor yang kuat pada intensi berperilaku dan perilaku nyata. Demikian pula norma subjektif yang juga berperan penting sebagai prediktor intensi berperilaku dan perilaku nyata (Dharmmesta, 1998).

Teori lainnya adalah teori perilaku rencanaan (Theory of Planned Behavior) atau selanjutnya disebut TPB. TPB menjelaskan bahwa prediktor intensi berperilaku ada tiga anteseden penting, meliputi: sikap, norma subjektif dan kontrol keperilakuan (persepsi resiko) (Ajzen, 1985). Ajzen berpendapat bahwa perilaku dengan keterlibatan tinggi menghadirkan anteseden persepsi resiko atau kontrol keperilakuan ini. Hasil empiris menunjukkan bahwa kewirausahaan merupakan perilaku dengan keterlibatan tinggi (Tjahjono dan Ardi, 2008) dengan menggunakan TPB berperan menjelaskan intensi mahasiswa berwirausaha. Dalam penelitiannya dijelaskan bahwa sikap dan kontrol keperilakuan berpengaruh pada keputusan mahasiswa berwirausaha di salah satu perguruan tinggi swasta di Yogyakarta.

Teori yang juga terkait erat dengan teknologi informasi sekaligus dapat men- 
jelaskan motif berwirausaha adalah model penerimaan teknologi (Technology Acceptance Model) selanjutnya disebut TAM. TAM merupakan teori yang dikembangkan Davis (1989). Beberapa peneliti lain yang menggunakan model ini di antaranya adalah Adam et al. (1992), Szajna (1994), Chin and Todd (1995), Iqbaria et al. (1997), Venkantesh and Morris (2000), Tjahjono and Wulandari (2008), dan Palupi and Tjahjono (2008).

TAM dibangun Davis (1989) berbasis TRA yang dikembangkan Fishbein and Ajzen (1975). Dalam teorinya, Davis menjelaskan bahwa terdapat dua anteseden penting dalam menjelaskan intensi berperilaku menggunakan teknologi, yaitu persepsi manfaat (perceived usefulness) dan persepsi kemudahan (perceived ease of use).

Dalam penelitian ini memodifikasi model TAM dengan TRA dan kepribadian berwirausaha. Menurut peneliti, sikap dalam TPB dapat memuat variabel persepsi manfaat dalam TAM yang berperan memprediksi intensi. Sedangkan anteseden kontrol keperilakuan/persepsi resiko dapat memuat variabel persepsi kemudahan dalam memprediksi intense selanjutnya disebut persepsi resiko. Variabel lain yang digunakan dalam penelitian ini adalah norma subjektif mengingat dalam budaya Indonesia terlebih Yogyakarta, variabel ini menjelaskan bahwa keputusan-keputusan individu tidak terlepas dari tuntutan lingkungan eksternal dalam memprediksi intensi.

Variabel lain yang diajukan dalam penelitian ini adalah kecenderungan orang berwirausaha yang sudah terbangun dalam diri seseorang karena pembelajaran individu. Variabel ini memodifikasi konsep yang diajukan Robinson et al. (1991) dan Tamizharasi and Panchanatam (2010) mengenai kecenderungan berwirausaha yang bersifat relatif melekat (embedded) selanjutnya peneliti menyebut sebagai kepribadian berwirausaha.

Dengan demikian dalam konteks berwirausahan penelitian ini mengkombinasikan kepribadian, TPB dan TAM. Teori utama yang mendasarinya adalah teori kognitif sosial (Social Cognitive Theory) yang diajukan Wood and Bandura (1989) bahwa terdapat interaksi aspek internal individu dan lingkungan dalam memprediksi intensi dan perilaku.

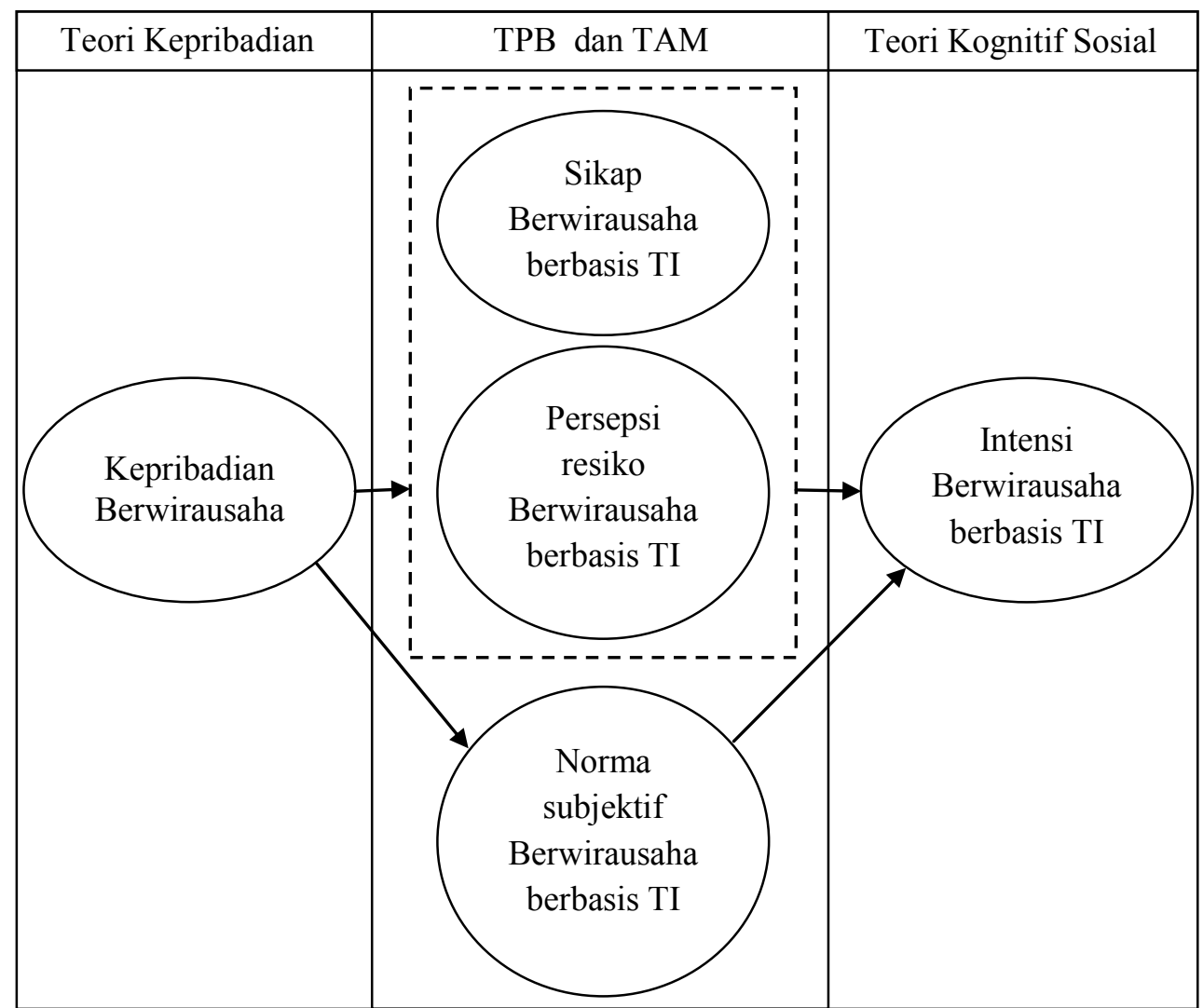

Gambar 1: Model Intensi Berwirausaha Berbasis TI, Tjahjono dan Palupi (2014) 


\section{Pengaruh Kepribadian Berwirausaha Pada Sikap Berwirausaha, Persepsi Resiko dan Norma Subjektif}

Kepribadian merupakan pola unik dan relatif permanen dari cara berpikir, pengelolaan emosi dan dorongan melakukan tindakan (Greenberg, 2011). Berbasis pada konsepsi Robinson et al. (1991) dan Tamizharani and Panchanatam (2010) selanjutnya disebut kepribadian berwirausaha (Tjahjono dan Palupi, 2014) merupakan basis dalam penjelasan seseorang bersikap dan berpersepsi dalam menjalankan aktifitas wirausaha. Kecenderungan kepribadian seseorang yang telah terbangun dalam diri individu (embedded) berperan dalam menjelaskan proses kognitif seperti sikap, persepsi resiko dan norma subjektif. Dengan demikian hipotesis penelitian sebagai berikut.

H1: Kepribadian berwirausaha berpengaruh positif pada sikap berwirausaha berbasis TI.

$\mathrm{H} 2$ : Kepribadian berwirausaha berpengaruh positif pada persepsi resiko berwirausaha berbasis TI.

H3: Kepribadian berwirausaha berpengaruh positif pada norma subjektif berbasis TI.

\section{Pengaruh Sikap, Persepsi Resiko dan Norma Subjektif Pada Intensi Berwirausaha}

Dalam TRA dan TPB dijelaskan bahwa aspekaspek kognitif berpengaruh pada niat berperilaku (Fishbein dan Ajzen, 1975, Dharmmesta, 1998). Demikian pula dalam TAM dijelaskan bahwa proses kognitif seperti persepsi kemudahan dan kemanfaatan berdampak pada intensi - lihat Davis (1989), Adam et al. (1992), Szajna (1994), Chin and Todd (1995), Iqbaria et al. (1997), Venkantesh \& Morris (2000). Beberapa hasil penelitian empiris telah menunjukkan dukungannya (Tjahjono dan Wulandari (2008), dan Palupi dan Tjahjono, 2014) bahwa aspek kognitif tersebut berdampak pada intensi berperilaku. Berdasarkan hal tersebut maka hipotesis penelitian ini adalah.

H4: Sikap berwirauhsa berbasis TI berpengaruh positif pada intensi berwirausaha berbasis TI.

H5: Persepsi resiko berwirausaha berbasis TI berpengaruh positif pada intensi berwirausaha berbasis TI.

H6: Norma subjektif berwirausaha berbasis TI berpengaruh positif pada intensi berwirausaha berbasis TI.

\section{METODE PENELITIAN}

Metode pengumpulan data yang dilakukan dalam penelitian ini adalah menggunakan kuesioner, yaitu penyebaran daftar pertanyaan kepada responden yang langsung diisi responden untuk mendapatkan jawaban dari responden mengenai kepribadian berwirausaha, sikap, norma subjektif dan persepsi resiko dan intensi untuk berwirausaha. Responden penelitian ini adalah para mahasiswa berbagai jurusan di perguruan tinggi di propinsi Daerah Istimewa Yogyakarta. Penentuan perguruan tinggi dilakukan dengan purposive, diperoleh empat perguruan tinggi besar terdiri atas satu perguruan tinggi negeri dan tiga perguruan tinggi swasta yang memiliki mahasiswa cukup besar. Sedangkan mahasiswa dipilih sebagai sampel dilakukan dengan cara yang sama yaitu purposive, yaitu atas dasar kriteria tertentu yaitu mahasiswa telah menempuh mata kuliah kewirausahaan.

Dalam penelitian ini data primer diperoleh secara langsung dari subjek dengan cara pengisian daftar pertanyaan mengenai sikap, referensi, persepsi resiko yang dirasakan dan intensi responden untuk menjadi wirausaha. Sedangkan data sekunder digunakan untuk membandingkan dan mempertajam pemahaman permasalahan, analisis dan pengayaan dalam melakukan studi ini.

Definisi Operasional dalam penelitian ini sebagai berikut:

\section{Kepribadian Berwirausaha $\left(\mathbf{X}_{1}\right)$}

Kecenderungan seseorang untuk berwirausaha. Kecenderungan itu bersifat relatif melekat (embedded) hasil dari pembelajaran individu. Instrumen dimodifikasi dari item Robinson et al. (1991) dimodifikasi peneliti dalam penelitian ini melalui FGD, lihat Tjahjono dan Palupi (2014).

\section{Sikap $\left(\mathbf{X}_{2}\right)$}

Sikap adalah kondisi kesiapan mental dan moral yang terorganisir melalui pengalaman, penggunaan pengaruh yang terarah dan dinamis pada respon individu ke semua obyek dan situasi yang terkait. Dan sikap tersebut sebagai suatu perasaan atau evaluasi umum (positif atau negatif) tentang orang, obyek atau persoalan (Fishbein dan Ajzen, 1985). Instrumen dimodifikasi melalui FGD, lihat Tjahjono dan Palupi (2014). 


\section{Norma subjektif $\left(\mathbf{X}_{3}\right)$}

Norma subjektif merupakan suatu upaya untuk mencakup pengaruh-pengaruh non-kesikapan pada intensi dan implikasinya pada perilaku, dengan menyertakan pertimbangan tekanan sosial yang dirasakan untuk memasukan perhitungan intensi keperilakuan (Fishbein dan Ajzen, 1985). Instrumen dimodifikasi melalui FGD, lihat Tjahjono dan Palupi (2014).

\section{Persepsi resiko $\left(\mathrm{X}_{4}\right)$}

Kontrol keperilakuan yang dirasakan merupakan suatu kondisi di mana orang percaya bahwa suatu tindakan itu mudah atau sulit untuk dilakukan (Dharmmesta, 1998). Pertanyaan dalam variabel ini terdiri dari 3 item pertanyaan yang dikembangkan peneliti merujuk pada artikel Fishbein dan Ajzen (1985). Instrumen dimodifikasi melalui FGD, lihat Tjahjono dan Palupi (2014).

\section{Intensi (Y)}

Intensi adalah tahapan kecenderungan individu untuk bertindak sebelum keputusan terakhir untuk berperilaku benar-benar dilaksanakan (Fishbein dan Ajzen, 1985). Instrumen dimodifikasi melalui FGD, lihat Tjahjono dan Palupi (2014).

\section{HASIL DAN PEMBAHASAN}

Bab ini menyajikan hasil penelitian survei yang ditujukan untuk menguji pengaruh sejumlah anteseden terhadap intensi mahasiswa berwirausaha dengan basis teknologi informasi. Temuan dalam penelitian ini menunjukkan bahwa sejumlah anteseden seperti sikap dan norma subjektif berperan penting dalam menjelaskan fenomena intensi mahasiswa berwirausaha dengan basis teknologi informasi. Temuan juga menunjukkan bahwa kontrol keperilakuan tidak berpengaruh terhadap intensi mahasiswa berwirausaha.

Populasi penelitian ini adalah mahasiswa perguruan tinggi di Yogyakarta yang telah memperoleh mata kuliah kewirausahaan. Pengumpulan data dilakukan pada tanggal $10-24$ Juni 2013 pada masing-masing universitas dikelola oleh dua asisten peneliti yang berperan sebagai enumerator. Kuesioner yang disebarkan berjumlah 300 dan kembali 238. Beberapa data tidak lengkap dan selanjutnya data yang dapat diproses sejumlah 211 .

\section{Statistik Deskriptif}

Untuk memberi makna pada sebaran data pada masing-masing variabel dilakukan kategorisasi dengan lima interval sebagai tampak pada tabel 2.

Statistik deskriptif menunjukkan sebaran sebagaimana tampak pada tabel 3 . Tabel tersebut juga menunjukkan hasil rata-rata jawaban responden untuk masing-masing variabel.

Data deskriptif tersebut menjelaskan bahwa kepribadian berwirausaha reponden penelitian tergolong baik. Dengan menggunakan sampel mahasiswa pada empat perguruan tinggi di provinsi Daerah Istimewa Yogyakarta menunjukkan hasil bahwa secara umum kepribadian berwirausaha mereka sudah masuk kategori baik. Demikian pula sikap berwirausaha mahasiswa berbasis TI di provinsi Daerah Istimewa Yogyakarta termasuk kategori baik. Intensi mereka untuk menjadi wirausaha berbasis TI juga masuk kategori baik sehingga dapat mendukung Yogyakarta sebagai kota industri paling kreatif di Indonesia.

Tabel 1: Informasi Kuesioner dapat diolah

\begin{tabular}{clcc}
\hline No & \multicolumn{1}{c}{ Keterangan } & Jumlah & $\%$ \\
\hline 1. & Kuesioner yang disebarkan & 300 & $100 \%$ \\
2. & Kuesioner yang direspon (kembali) & 238 & $79,333 \%$ \\
3. & Kuesioner yang dapat diolah & 211 & $70,333 \%$ \\
\hline
\end{tabular}

Sumber: Data diolah

Tabel 2: Kategorisasi Berdasar Interval

\begin{tabular}{cc}
\hline Interval & Kategori \\
\hline $2,00-2,60$ & Sangat Rendah \\
$2,61-3,20$ & Rendah \\
$3,21-3,80$ & Sedang \\
$3,81-4,40$ & Baik \\
$4,41-5,00$ & Sangat Baik \\
\hline
\end{tabular}


Tabel 3: Rata-Rata Hitung Tiap Variabel

\begin{tabular}{lcc}
\hline \multicolumn{1}{c}{ Variabel } & Mean (Rata-rata hitung) & Kategori \\
\hline Kepribadian berwirausaha & 3,85 & Baik \\
Sikap berwirausaha berbasis TI & 3,88 & Baik \\
Norma subjektif berwirausaha berbasis TI & 3,53 & Sedang \\
Persepsi resiko berwirausaha berbasis TI & 3,52 & Sedang \\
Intensi berwirausaha berbasis TI & 3,94 & Baik \\
\hline
\end{tabular}

Data deskriptif juga menunjukkan bahwa norma subjektif mahasiswa di Yogyakarta dalam berwirausaha tergolong sedang. Artinya dalam berwirausaha, mahasiswa Yogyakarta tidak terlalu tergantung pada pandangan lingkungan mereka. Demikian pula dengan persepsi resiko mereka juga tergolong sedang. Konsepsi pengendalian resiko mahasiswa Yogyakarta lebihj moderat dan mereka mempunya cukup perhitungan untuk pengambilan keputusan. Kedua hal tersebut apabila dibandingkan dengan sikap berwirausaha menunjukkan bahwa mahasiswa di Yogyakarta relatif lebih mandiri. Mereka tidak terlalu bergantung pada pandangan referensi lingkungan, akan tetapi mereka lebih mempunyai sikap berwirausaha berbasis TI yang lebih dominan.

Data di lapangan menunjukkan bahwa mahasiswa Yogyakarta banyak yang sudah terlibat bisnis sejak mahasiswa. Sebagai contoh bisnis yang sangat kreatif adalah Dagadu yang bergerak sebagai industri kreatif dengan menggunakan pilihan kata yang dituliskan pada kaos. Demikian pula Steak and Shake, Spesial Sambal, Cinamon dan lain-lain membentuk komunitas bisnis kaum muda. Pada umumnya mereka sukses dan berhasil sehingga menjadi inspirasi para mahasiswa di Yogyakarta untuk mengembangkan bisnis saat ini ataupun masa depan mereka.

\section{Pengujian Validitas dan Reliabilitas}

Pengujian ini menguji kemampuan alat ukur dalam mengukur konsep yang seharusnya diukur. Dalam studi kuantitatif, pengujian ini sangat penting karena indikator-indikator yang diguanakan harus secara cermat mengukur konsep yang diukur tersebut, baik terkait dengan validitas tampang (face validity) dan validitas isi (content validity).

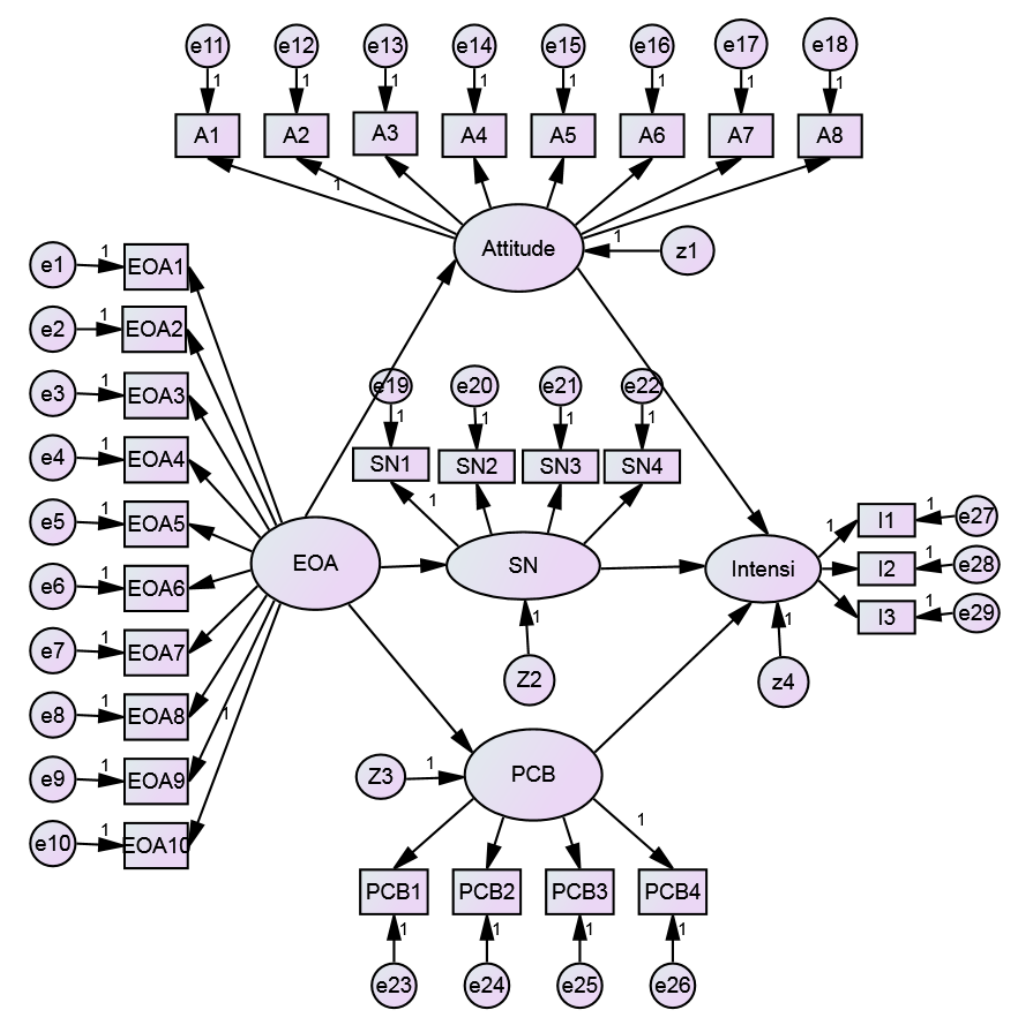


Pengujian validitas konstruk dengan analisis faktor yang menggunakan rotasi varimax. Rotasi ini memberikan hasil yang baik dalam memaksimalkan jumlah variansi yang dapat membedakan faktor-faktor dengan jelas (Hair et al., 2006). Peneliti menggunakan loading factor sebesar 0,5. Hasil menunjukkan bahwa keseluruhan indikator-indikator menunjukkan hasil yang valid dalam mengukur variabelvariabel penelitian. Pengujian reliabilitas merupan pengukuran untuk mengukur sejauh mana konsistensi internal dari suatu instrumen penelitian. Hasil menunjukkan bahwa instrumen penelitian dapat diandalkan atau reliabel.

Pengujian validitas konstruk dengan analisis faktor yang menggunakan rotasi varimax. Rotasi ini memberikan hasil yang baik dalam memaksimalkan jumlah variansi yang dapat membedakan faktor-faktor dengan jelas (Hair et al., 2006). Peneliti menggunakan loading factor sebesar 0,5. Hasil menunjukkan bahwa keseluruhan indikator-indikator menunjukkan hasil yang valid dalam mengukur variabelvariabel penelitian. Pengujian reliabilitas merupan pengukuran untuk mengukur sejauh mana konsistensi internal dari suatu instrumen penelitian. Hasil menunjukkan bahwa instrumen penelitian dapat diandalkan atau reliabel.

\section{Uji Hipotesis}

Interpretasi hasil uji hipotesis disajikan pada tabel 4. Berdasarkan tabel tersebut ditunjukkan bahwa semua hipotesis signifikan terbukti dari nilai probability value dengan *** yang berarti signifikansi terlalu kecil sehingga berada di bawah $\alpha 0,05$. Disamping itu dapat dilihat dari nilai critical ratio yang berada di atas 2 menunjukkan bahwa hipotesis terbukti signifikan.

Hasil penelitian ini secara empiris menunjukkan bahwa kepribadian berwirausaha mempunyai pengaruh positif pada sikap berwirausaha. Hasil juga menunjukkan bahwa kepribadian berwirausaha memiliki pengaruh positif pada norma subjektif berwirausaha dan berpengaruh positif juga pada persepsi resiko.

Sementara itu sikap berwirausaha dalam penelitian ini memprediksi secara positif intensi mahasiswa berwirausaha. Demikian pula norma subjektif berwirausaha juga berperan sebagai variabel yang menjelaskan intensi mahasiswa berwirausaha.

Sedangkan pada hipotesis tentang PCB tidak didukung yaitu pengaruh persepsi resiko terhadap Intention terbukti tidak signifikan karena probability value sebesar 0,740 lebih besar dari $\alpha$ 0,05 , dan critical ratio sebesar 0,332 lebih kecil dari 2.

Tabel 4: Interpretasi hasil uji hipotesis

\begin{tabular}{lccl}
\hline \multicolumn{1}{c}{ Hipotesis } & Critical Ratio & Probability & \multicolumn{1}{c}{ Keterangan } \\
\hline Attitude $\leftarrow$ EOA & 5,193 & $* * *$ & Signifikan \\
SN $\leftarrow$ EOA & 4,635 & $* * *$ & Signifikan \\
PCB $\leftarrow$ EOA & 5,781 & $* * *$ & Signifikan \\
Intention $\leftarrow$ Attitude & 5,470 & $* * *$ & Signifikan \\
Intention $\leftarrow$ Subjective Norm & 5,443 & $* * *$ & Signifikan \\
Intention $\leftarrow$ PCB & 0,332 & 0,740 & Tidak Signifikan \\
\hline
\end{tabular}

\section{Goodness of Fit Index}

Tabel 5: Evaluasi Kriteria Goodness of Fit Model (Lee, Park, \& Ahn, 2001)

\begin{tabular}{clccc}
\hline No & \multicolumn{1}{c}{ Kriteria } & Nilai rekomendasi & Hasil Model ini & Ket \\
\hline 1. & Chi-square $\left(\mathrm{X}^{2}\right)$ & $\begin{array}{c}\text { Diharapkan kecil } \mathrm{X}^{2} \text { dengan } \\
\mathrm{df}=344 \text { adalah } 388.2509^{*}\end{array}$ & 736.426 & Buruk \\
2. & $\mathrm{X}^{2}$ - significance probability & $\geq 0.05$ & 0.00 & Buruk \\
3. & Relative $\mathrm{X}^{2}$ (CMIN/DF) & $\leq 2.00$ & 2.141 & Marjinal \\
4. & GFI (Goodness of Fit Index) & $\geq 0.90$ & 0.780 & Marjinal \\
5. & AGFI (Adjusted Goodness of Fit Index) & $\geq 0.80$ & 0.740 & Marjinal \\
6. & Tucker-Lewis Index (TLI) & $\geq 0.90$ & 0.781 & Marjinal \\
7. & Normed Fit Index (NFI) & $\geq 0.90$ & 0.686 & Marjinal \\
8. & Comparative Fit Index (CFI) & $\geq 0.90$ & 0.801 & Marjinal \\
9. & Root Mean Square Error of Approximation (RMSEA) & $\leq 0.08$ & 0.076 & Baik \\
\hline
\end{tabular}

*) 344,2509 diperoleh dari program excel pada menu CHIINV, dengan probabilitas 0.05 dan degree of freedom (df) sebesar 344 (diperoleh dari hasil output AMOS). 
Hasil kriteria goodness of fit menunjukkan bahwa hanya pada kriteria RMSEA yang berada dalam kategori baik. Nilai RMSEA menunjukkan goodness of fit yang dapat diharapkan bila model diestimasi dalam populasi (Hair, 2006). Mayoritas kriteria adalah marjinal yang menunjukkan model in sebenarnyai tidak terlalu baik, dan jika diperlukan dapat dilakukan modifikasi model.

Hasil penelitian menunjukkan bahwa karakteristik atau kepribadian berwirausaha berperan penting dalam memprediksi sikap seorang mahasiswa dalam berwirausaha. Hal ini menunjukkan bahwa aspek kepribadian penting dibangun karena di dalamnya terkait dengan skema berpikir mereka dalam bersikap terkait dengan berwirausaha. Dalam Greenberg (2011) dijelaskan bahwa kepribadian berkaitan dengan skema berpikir dan merasakan serta bagaimana berperilaku yang relatif permanen dalam diri individu. Semakin kuat kepribadian berwirausaha semakin kuat pula sikap untuk berwirausaha.

Kepribadian berwirausaha berdampak positif pula pada norma subjektif. Dalam kepribadian skema berpikir memegang peranan penting sehingga kepribadian kuat berwirausaha dapat meningkatkan persepsi norma subjektif yang didalamnya adalah keyakinan normatif dan motivasi untuk mengikuti keyakinan normatif tersebut. Ini bermakna bahwa semakin kuat kepribadian berwirausaha mendorong semakin kuatnya norma subjektif berwirausaha.

Kepribadian berwirausaha juga berdampak positif pada persepsi resiko. Skema berpikir dan perasaan kuat berwirausaha memiliki peran kuat dalam pembentukan persepsi bahwa seseorang semakin siap mengendalikan resiko dalam berwirausaha. Dengan demikian semakin kuat kepribadian seseorang berwirausaha menyebabkan semakin kuat pula kesiapan dalam mengenalikan resiko dalam berwirausaha. Dengan demikian hipotesis 1,2 dan 3 dalam penelitian ini didukung.

Apabila dibandingkan besar pengaruh kepribadian berwirausaha pada sikap berwirausaha berbasis TI, pada norma subjektif berwirausaha berbasis TI dan pada persepsi resiko berbasis TI menunjukkan bahwa pengaruh tersebut lebih kuat pada aspek sikap berwirausaha dan persepsi seseorang pada resiko berbasis TI. Dengan demikian kepribadian berwirausaha lebih berpengaruh pada kemandirian individu dibandingkan dengan aspek eksternal seperti norma subjektif.

Hasil penelitian juga menunjukkan bahwa sikap berwirausaha berbasis TI memiliki pengaruh positif pada intensi berwirausaha berbasis TI. Sikap yang terdiri atas keyakinan dan evaluasi berdampak positif pada intensi berwirausaha berbasis TI. Keyakinan bahwa berwirausaha memiliki prospek dan produktif bagi individu mendorong mereka semakin berkeinginan (memiliki intensi kuat) untuk berwirausaha berbasis TI. Demikian pula evaluasi pentingnya prospek dan produktifitas masa depan menjadikan seseorang berkeinginan untuk menjadi wirausaha berbasis TI. Kedua hal tersebut berdampak positif pada intensi mereka menjadi seorang wirausaha berbasis TI.

Konsep sikap di dalamnya juga mengandung sejumlah indikator terkait persepsi manfaat dan persepsi kemudahan terkait dengan wirausaha berbasis TI. Semakin seseorang mempersepsikan bahwa menjadi wirausaha yang menggunakan basis TI adalah bermanfaat bahkan sangat bermanfaat menjadikan mereka semakin berkeinginan menjadi wirausaha berbasis TI. Pada aspek yang lain, seseorang yang mempersepsikan bahwa penggunaan teknologi informasi untuk berwirausaha mudah semakin mendorong mereka menjalankan wirausaha berbasis TI.

Konsep norma subjektif adalah keyakinan normatif pada referen lingkungan mahasiswa seperti teman, sahabat, pacar, orang tua dan lain-lain yang berhubungan dengan proses pengambilan keputusan mereka, termasuk di dalamnya motivasi untuk mengikuti pandangan lingkungan. Konsep norma subjektif berpengaruh positif pada intensi berwirausaha berbasis pada TI. Semakin kuat norma subjektif berwirausaha semakin mendorong intensi mahasiswa berwirausaha dengan menggunakan TI. Semakin kuat pandangan lingkungan untuk mendorong mereka berwirausaha menjadikan mereka semakin memiliki intensi kuat untuk berwirausaha dengan basis TI. Demikian pula semakin kuat motivasi mengikuti pandangan tersebut semakin kuat pula intensi untuk berwirausaha dengan basis TI. Hasil-hasil tersebut menunjukkan bahwa hipotesis 4 dan 6 didukung, kecuali hipotesis 5. 
Konsep norma subjektif di dalamnya juga mengandung sejumlah indikator terkait persepsi manfaat dan kemudahan. Semakin seseorang mempersepsikan pandangan lingkungan bahwa menjadi wirausaha yang menggunakan basis TI adalah bermanfaat bahkan sangat bermanfaat menjadikan mereka semakin berkeinginan menjadi wirausaha berbasis TI. Pada aspek yang lain, seseorang yang mempersepsikan motivasi mengikuti pandangan lingkungan bahwa penggunaan teknologi informasi untuk berwirausaha yang mudah berdampak semakin mendorong mereka menjalankan wirausaha berbasis TI.

Hasil penelitian menunjukkan persepsi resiko tidak berpengaruh pada intensi berwirausaha dengan basis TI. Dengan menggunakan dimensi TAM yaitu persepsi kemudahan maka semakin mudah penggunaan teknologi informasi untuk berwirausaha mendorong mereka berintensi untuk berwirausaha dengan menggunakan TI. Hasil yang tidak signifikan berarti persepsi resiko bukanlah faktor utama dalam menjelaskan intensi berwirausaha dengan basis TI. Dimungkinkan anteseden lain seperti sikap dan norma subjektif lebih memiliki pengaruh yang dominan dalam konteks mahasiswa ini.

\section{PENUTUP}

Penelitian ini membahas kepribadian berwirausaha dan pengaruh sikap berwirausaha, norma subjektif, dan persepsi resiko dalam berwirausaha berbasis TI pada intensi mahasiswa berwirausaha berbasis pada TI. Hasil deskriptif menunjukkan bahwa kepribadian berwirausaha mahasiswa yang menjadi responden di Provinsi Daerah Istimewa Yogyakarta termasuk kategori baik. Demikian pula sikap berwirausaha dan intensi mahasiswa untuk berwirausaha dengan basis TI tergolong baik.

Hasil penelitian juga menunjukkan bahwa kepribadian berwirausaha memiliki pengaruh positif pada sikap berwirausaha, norma subjektif berwirausaha dan persepsi resiko berwirausaha berbasis TI. Sedangkan sikap berwirausaha, norma subjektif berwirausaha berbasis TI memiliki pengaruh positif pada intensi mahasiswa berwirausaha dengan basis TI.

Hasil lainnya menunjukkan bahwa persepsi resiko berwirausaha berbasis TI tidak berpengaruh pada intensi mahasiswa berwirausaha dengan basis TI. Hasil ini dimungkinkan oleh kuatnya dua anteseden lainnya yaitu sikap berwirausaha dan norma subjektif berwirausaha yang lebih berperan. Hal yang menarik adalah kedua anteseden tadi representasi TRA. Tambahan persepsi resiko menyebabkan TRA menjadi TPB. Hal ini menjadi agenda penelitian ke depan untuk menguji apakah modifikasi TPB dengan TAM mendapat dukungan empiris yang kuat.

Secara teoritik, penelitian ini telah memberikan gambaran bahwa modifikasi konsep TAM dan TPB telah menjelaskan fenomena intensi mahasiswa berperilaku dalam hal ini keinginan menjadi wirausaha berbasis TI. Hasil menunjukkan dukungan yang kuat pada sejumlah anteseden kecuali persepsi resiko. Tidak didukungnya persepsi resiko menunjukkan bahwa pengendalian terhadap resiko bukan pertimbangan pokok dalam memutuskan berwirausaha berbasis TI bagi mahasiswa. Hal tersebut dimungkinkan tingkat keterlibatan mahasiswa terhadap investasi dipersepsikan tidak terlalu tinggi atau masuk kategori low involvement. Dengan demikian secara umum mereka lebih siap menghadapi resiko dalam berwirausaha berbasis TI.

Pada aspek fenomena mahasiswa di Yogyakarta mempunyai kepribadian berwirausaha, sikap, norma subjektif dan intensi berwirausaha berbasis TI yang cukup baik. Profil statistik deskriptif menunjukkan bahwa para mahasiswa tersebut mempunyai potensi untuk pengembangan kewirausahaan di Yogyakarta. Hal ini berarti provinsi Daerah Istimewa Yogyakarta mempunyai potensi besar mengembangkan diri sebagai kota industri kreatif yang mandiri dengan dukungan mahasiswa yang memiliki antusiasme menjadi sosok wirausaha berbasis TI.

Dari aspek sikap kepribadian berwirausaha, sikap berwirausaha dan persepsi resiko menunjukkan bahwa mahasiswa relatif lebih mandiri dalam pengambilan keputusan bisnis apabila dibandingkan dengan aspek norma subjektif. Ini menunjukkan bahwa modal manusia wirausaha potensial berkembang di Yogyakarta.

Penting bagi lembaga pendidikan termasuk perguruan tinggi untuk mendesain pembelajaran yang mendorong kualitas mental dalam berwirausaha terkait dengan kuatnya 
peranan mereka mendorong intensi berwirausaha. Dengan demikian desain pembelajaran yang mendorong kepribadian mental wirausaha seperti kemampuan mental bersahabat dengan tantangan, kemampuan berjejaring, dan kemandirian menjadi isu penting dalam desain tersebut.

Hasil penelitian empiris ini menunjukkan bahwa TPB yang dimodifikasi dengan TAM secara umum didukung, namun variabel persepsi resiko tidak mendapat dukungan empiris. Dengan kata lain justru model TRA yang mendapat dukungan. Oleh karena itu penelitian ke depan penting untuk melakukan pengujian modifikasi TPB dengan TAM pada fenomena yang lebih sesuai.

Penelitian ini dilakukan dengan pendekatan non random sehingga generalisasi terhadap populasi dalam hal ini mahasiswa di provinsi Daerah Istimewa Yogyakarta relatif rendah. Penting bagi penelitian ke depan meskipun sulit menggunakan random, mempertimbangkan modifikasi non random seperti cluster daerah ataupun kuota untuk memperkuat keterwakilan populasi misalnya dengan mempertimbangkan berbasis kabupaten atau berbasis ukuran perguruan tinggi/ jenis perguruan tinggi dan lain-lain.

Pengayaan keyakinan, nilai-nilai dan asumsi dasar di balik sikap dan perilaku mahasiswa belum tereksplorasi dengan baik sehingga penelitian ke depan penting mempertimbangkan metode wawancara sebagai komplemen dari penelitian ini.

Validitas internal dalam penelitian survei relatif lemah. Oleh karena itu perlu upaya pengujian eksperimen untuk memastikan prediksi tersebut atau paling tidak dengan diskusi mendalam mengenai ketiga variabel anteseden yang diajukan dalam model. Di samping itu, keyakinan bahwa tiga variabel anteseden adalah variabel prediktor terbaik dalam menjelaskan intensi mahasiswa berwirausaha berbasis TI masih perlu pengujian pada berbagai setting yang lebih kompleks.

\section{DAFTAR PUSTAKA}

Adam, DA., RR. Nelson dan PA.Todd. 1992. Perceived usefulness, Ease of Use and Usage of Information Technology: A Replication. MIS Quarterly. 16 (2). 227-250.
Ajzen, I. 1985. From intentions to actions: a theory of planned behavior dalam $\mathrm{J}$ Kuhl \& J. Beckmann (Eds.). ActionControl: From Cognition to Behavior. Springer, Heidelberg. 11-39.

Chin, WW. and P. Todd. 1991. On the use usefullness, ease of use of structural equation modelling in MIS research: a note of caution. MISQ. 19(2). 237-246.

Davis, FD. 1989. Perceived Usefulness, Perceived Ease of Use of Structural Equation Modeling in MIS Research: A Note of Caution. MIS Quarterly. 19.237-246.

Dharmmesta, BS. 1998. Theory of Planned Behavior dalam Penelitian Sikap, Niat dan Perilaku Konsumen. Jurnal Kelola. 18.

Gefen, D. and DW. Straub. 1997. Gender Differences in the Perception and Use E-mail: An Extension to the Technology Acceptance Model. MIS Quarterly. Desember. 389-400.

Fishbein and Ajzen, I. 1975. Belief, Attitude, Intention and Behavior. London: Addison Wesley Publishing Co. Journal. 32(1). 115-130.

Greenberg, J. 2011. Behavior in Organizations. Pearson Education Limited. $10^{\text {th }}$ Edition.

Hair J.F., RE. Anderson, RL.Tatham and WC. Black. 2006. Multivariate Data Analysis, Prentice-Hall International, United States of America.

Hasan, S. 2012. Rasio kewirausahaan Indonesia meningkat menjadi $1,56 \%$. Diunduh: http://article.wn.com/view/2014/02/16/ Masalah_koordinasi_hambat_kesukses an_program_kewirausahaan/

Igbaria, MN., PC. Zinaelli, and LM. Cavaye. 1997. Personal Computing Acceptance Factors in Small Firms: A Structural Equation Model. MIS Quarterly. 21(3). 279-305.

Mathieson, K. 1991. Predicting User Intentions: Comparing the Technology Acceptance Model with the Theory of 
Planned Behavior. Information System Research. 2. 173-191.

Palupi, M. dan HK. Tjahjono. 2008. Aplikasi Technology Acceptance Model dengan Mempertimbangkan Gender Pada Perilaku Penggunaan Internet. Jurnal Ekonomi dan Bisnis. 9 (2).147-166

Robinson, PB., DV. Stimpson, JC. Huefner and HK. Hunt. 1991. An attitude approach to the prediction of entrepreneurship theory and practice. 15(4).13-31.

Szajna, B. 1994. Software Evaluation and Choice: Predictive Validation of the Technology Acceptance Instrument. MISQ. 13 (3). 319-324.

Tamizharasi, G. and N. Panchanatam. 2010. Entrepreneurial attitudes among entrepreneurs in small and medium enterprise. International Journal of Innovation, Management and Technology. 1 (4). 354-356.

Tjahjono, HK. dan H. Ardi. 2008. Kajian Niat Mahasiswa Manajemen UMY Menjadi Wirausaha. Jurnal Utilitas UMY.
Tjahjono, HK. dan Y. Wulandari. 2008. Implementasi Model Penerimaan Teknologi pada Organisasi: Kajian Intensi Dosen Menggunakan Teknologi E-Learning. 20 (1). 42-51.

Tjahjono, HK dan Palupi, M. 2014. Model Intensi Berwirausaha Berbasis Teknologi Infofrmasi. Jurnal Bisnis Teori dan Implementasi. 8 (1). 1-12

Venkatesh, V. and Davis, FD. 1996. A Model of the Perceived Ease of Use Development and Test,. Decision Sciences. 27(3). 451-481.

Venkatesh, V. and M.G. Morris. 2000. Why Don't Men Ever Stop to Ask for Direction? Gender Social Influence, and Their Role in Technology Acceptance and Usage Behavior. MIS Quarterly. 24 (1). 115-139.

Wood, R and A. Bandura. 1989. Social cognitive theory of organizational management. Academy of Management Review. (14). 361-384. 